\title{
Pengaruh Penggunaan Protein dan Kultur Khamir Dalam Ransum Terhadap Mortalitas Embrio Ayam Arab
}

\author{
Nur Alim Natsir \\ Program Studi Pendidikan Biologi, IAIN Ambon \\ E-mail: nuralimnatsir@gmail.com
}

\begin{abstract}
Abstrak: Protein merupakan nutrien penting dalam ransum. Ketersediaan protein dalam ransum dibutuhkan secara mutlak sebagai sumber zat pembangun untuk pertumbuhan, pengganti jaringan yang rusak dan menjaga fungsi-fungsi reproduksi. Pada penyusunan ransum yang sempurna, keseimbangan energi dan protein, asam amino perlu diperhatikan karena menentukan dalam produktivitas dan reproduktivitas ternak ayam. Tujuan dari penelitian ini adalah untuk mengetahui pengaruh penggunaan protein dan kultur khamir dalam ransum terhadap mortalitas embrio ayam arab. Pengaruh yang diamati meliputi pengaruh interaksi dan pengaruh tunggal tingkat protein dan kultur khamir dalam ransum terhadap mortalitas embrio ayam arab. Materi penelitian adalah sebanyak 240 ekor "Ayam Arab" yang berumur 28 minggu sebagai hewan percobaan. Telur tetas hasil produksi selama penelitian (pada umur 28 sampai 36 minggu produksi). Metode penelitian yang digunakan adalah metode eksperimental dengan Rancangan Acak Lengkap Pola Faktorial 3 x 4 dengan 5 kali ulangan. Perlakuan yang diberikan berupa pemberian ransum isokalorik $(2850 \mathrm{kkal} / \mathrm{kg})$ dengan kadar protein yang berbeda $(13 \%, 15 \%$ dan $17 \%)$ dan kultur khamir dengan konsentrasi $(0 \% ; 0,2 \% ; 0,4 \%$; dan $0,6 \%)$. Ransum dan air minum diberikan secara ad libitum. Analsis data menggunakan ANAVA dengan uji lanjut menggunakan Uji Jarak Berganda Duncan's (Duncan's Multiple Range Test). Hasil penelitian menunjukkan bahwa tingkat penggunaan protein $13 \%, 15 \%$ dan $17 \%$ tidak berinteraksi dengan kultur khamir $0 \% ; 0,2 \% ; 0,4 \%$; dan $0,6 \%$ terhadap mortalitas embrio $(\mathrm{P}>0,5)$. Namun pengaruh tunggal protein ataupun kultur khamir dalam ransum, secara sendiri-sendiri memberikan pengaruh yang nyata terhadap mortalitas embrio $(\mathrm{P}<0,5)$ dengan hasil terbaik dicapai pada tingkat penggunaan protein $15 \%$ dan tingkat penggunaan kultur khamir 0,4\%. Disarankan bagi peternak untuk menggunakan ransum isokalorik $(2850 \mathrm{kkal} / \mathrm{kg})$ dengan protein $15 \%$ dengan kultur khamir 0,4\% karena memberikan efisiensi reproduksi telur tetas yang terbaik.
\end{abstract}

\section{Kata Kunci: Protein, Kultur Khamir, Ransum, Mortalitas, Embrio, Ayam Arab}

Abstract: Protein is an important nutrient in the diet. The availability of protein in the diet is absolutely necessary as a source of building blocks for growth, replacement of damaged tissue and maintaining reproductive functions. In the preparation of a perfect 
ration, the balance of energy and protein, amino acids need to be considered because they determine the productivity and reproduction of chickens. The purpose of this study was to determine the effect of the use of protein and yeast culture in the ration on the mortality of Arabic chicken embryos. The observed effects include the interaction effect and the single effect of protein level and yeast culture in the ration on the mortality of Arabic chicken embryos. The research material is as many as 240 "Arabic Chickens" aged 28 weeks as experimental animals. Hatch eggs produced during the study (at the age of 28 to 36 weeks of production). The research method used is an experimental method with a completely randomized design with a factorial pattern of $3 \times 4$ with 5 replications. The treatments given were isocaloric ration $(2850 \mathrm{kcal} / \mathrm{kg})$ with different protein content $(13 \%, 15 \%$ and $17 \%)$ and yeast culture with concentrations $(0 \% ; 0.2 \% ; 0.4 \%$; and $0.6 \%)$. Ration and drinking water are provided ad libitum. Data analysis using ANOVA with further testing using Duncan's Multiple Range Test (Duncan's Multiple Range Test). he results showed that the level of protein use $13 \%, 15 \%$ and $17 \%$ did not interact with yeast culture $0 \% ; 0.2 \% ; 0.4 \%$; and $0.6 \%$ on embryo mortality $(\mathrm{P}>0.5)$. However, the single effect of protein or yeast culture in the diet, individually gave a significant effect on embryo mortality $(\mathrm{P}<0.5)$ with the best results achieved at $15 \%$ protein use rate and $0.4 \%$ yeast culture use rate. It is recommended for breeders to use an isocaloric ration $(2850 \mathrm{kcal} / \mathrm{kg}$ ) with $15 \%$ protein with $0.4 \%$ yeast culture because it provides the best reproductive efficiency of hatching eggs.

\section{Keywords: Protein, Yeast Culture, Ration, Mortality, Embryo, Arabic Chicken}

Ransum merupakan faktor yang berpengaruh langsung terhadap terjadinya penurunan produksi telur dan kelainan-kelainan fisik yang dapat mengganggu keseimbangan produksi telur secara menyeluruh. Semua nutrien yang dibutuhkan oleh ayam harus terkandung dalam suatu formulasi ransum karena ayam tidak mampu mensintesis nutrien sebaik ternak ruminansia. Dalam hal ini keseimbangan nutrien perlu mendapatkan perhatian, karena kualitas ransum tidak hanya ditentukan oleh jumlah masing-masing nutrient yang terdapat di dalam ransum tetapi juga perimbangan antara nutrien tersebut (Scott et al., 1982). Defisiensi pakan dan nutrien tertentu seperti energi dan protein dapat menimbulkan hambatan pada perkembangan tubuh yang pada akhirnya akan menimbulkan gangguan atau kegagalan pada fungsi-fungsi reproduksi (Getty, 1975; Anggorodi, 1985; Tillman dkk, 1991). Pada penyusunan ransum yang sempurna, keseimbangan energi, protein, asam amino dan zat an organik essensial perlu diperhatika, sebab mempunyai hubungan yang erat dan menentukan dalam produktivitas dan reproduktivitas ternak ayam (Etches, 1993 dan Djanah, 1985). Dalam menjaga kesinambungan peningkatan produksi dan reproduksi ternak unggas, faktor pakan menentukan besar kecilnya keuntungan yang didapat, yang pengeluarannya berkisar

BIOLOGI SEL (VOL 9 NO 2 EDISI JUL-DES 2020 ISSN 2252-858X/E-ISSN 2541-1225) PAGE 205 
antara 60 sampai 70 persen dari biaya produksi. Sumber bahan pakan yang mudah didapat, tersedia dalam jumlah banyak dan berkesinambungan, mempunyai nilai nutrien yang tinggi serta tidak bersaing dengan manusia perlu dilakukan. Salah satu langkah yang bisa ditempuh untuk menekan biaya ransum diantaranya dengan memberikan feed additive dalam ransum ternak. Penggunaan feed additive seperti antibiotika dan hormon pertumbuhan telah banyak diberikan pada ternak unggas. Pemberian bahan-bahan kimia sebagai feed additive ini akan berdampak negatif yaitu adanya residu dalam telur dan daging ayam juga dapat menimbulkan gangguan atau kegagalan pada fungsi-fungsi reproduksi.

Upaya yang perlu dilakukan untuk menekan dampak negatif pemberian bahanbahan kimia sebagai feed aditive adalah menggunakan bahan pemacu pertumbuhan yang memiliki sifat antara lain: meningkatkan pertumbuhan ternak, memperbaiki fungsi reproduksi, mendukung efisiensi penggunaan ransum, memiliki mekanisme kerja fisiologis, tidak bersifat racun,efektif terhadap seluruh spesies ternak, dapat dimetabolisasi secara keseluruhan,tidak menyisakan residu, memiliki kestabilan yang tinggi, tidak memiliki interaksi dengan bahan-bahan lain penyusun ransum, tidak menimbulkan dampak polusi terhadap lingkungan dan memiliki nilai ekonomis yang tinggi (Sumantra, 1993).

Enzim merupakan feed additive yang ditambahkan dalam ransum dengan tujuan untuk mempercepat pencernaan ransum atau mempertinggi nilai cerna ransum sehingga pada akhirnya dapat mendukung perkembangan fungsi reproduksi secara optimal (Anggorodi, 1985). Enzim tersebut diperoleh dari makhluk hidup yaitu dengan jalan mengembangkan khamir dari jenis Saccharomyces cerevesiae dengan produk akhir berupa kultur khamir. Bekatul dapat digunakan sebagai substrat pengemban karena bekatul mempunyai kandungan karbohidrat dan protein yang cukup untuk memungkinkan pertumbuhan khamir.

Kultur khamir dalam saluran pencernaan akan mampu menghasilkan enzimenzim yang membantu proses pencernaan disamping merupakan upaya meningkatkan efisiensi penggunaan pakan dan mencukupi kebutuhan perkembangan terutama yang menyangkut fungsi reproduksi, namun tidak melebihi kebutuhan sehingga tidak terbentuk deposit lemak yang berlebih. Kultur khamir merupakan produk kering yang tersusun ataskhamir dan substratnya, pengeringan tersebut dimaksudkan untuk mengurangi aktivitas sebelum digunakan. Kultur khamir dalam tubuh akan memproduksi enzim amilase, protease, lipase dan pitase (Shin, 1988). Dengan demikian jumlah enzim dalam tubuh akan semakin bertambah, dengan penambahan jumlah enzim ini diharapkan dapat membantu pencernaan nutrien dan mempertinggi reproduktivitas dalam tubuh ternak (Anggorodi, 1985). Mengingat pada unggas ketersediaan enzim dalam saluran pencernaan sangat terbatas, maka penggunaan kultur khamir pada ransum ayam dapat sebagai alternatif memperbaiki fungsi fisiologis saluran pencernaan dan mencukupi 
kebutuhan perkembangan terutama yang menyangkut fungsi reproduksi.

Hasil penelitian yang dilakukan oleh Andayani, Susanto, Surisdiarto, Widodo dan Sjofjan (1989), dikemukakan bahwa penggunaan kultur khamir 0,25 persen dalam ransum ayam pedaging strain Lohman dapat meningkatkan pertambahan bobot badan sebesar 143 gram dan menurunkan konversi pakan sebesar 0,138 dan utilisasi mineral fosfor akan meningkat pada penggunaan kultur khamir dalam ransum ayam petelur (Shin, 1988).

Sebagaimana telah diuraikan bahwa protein merupakan nutrien yang penting dalam penyusunan ransum selain untuk hidup pokok, aktivitas reproduksi dan pertumbuhan jaringan. Mutu dan jumlah protein yang diberikan pada ternak merupakan faktor yang penting dan harus disesuaikan dengan pola pertumbuhan ternak. Persentase kandungan protein merupakan salah satu faktor yang mempengaruhi baik buruknya kualitas ransum (Rasyaf, 1989). Beberapa faktor lain yang mempengaruhi antara lain: imbangan energi protein, susunan dan imbangan asam amino serta status produksi dan reproduksi ternak yang bersangkutan. Ransum yang kekurangan satu atau beberapa asam amino dapat dipenuhi dengan jalan mengkombinasikan bahan penyusun ransum lainnya, sehingga diperoleh supplementary effect dari protein.

Hasil penelitian Sugandi, Bird dan Atmadilaga (1973) yang dikutip oleh Rasyaf (1992) tentang pengaruh tingkat protein dan energi terhadap penampilan ayam kampung di daerah tropik yang dicobakan pada enam macam ransum perlakuan, yaitu kombinasi dari dua tingkat protein (15 dan 17 persen) dengan tiga tingkat energi termetabolisasi (2650, 2850 dan $3050 \mathrm{kkal}$ per kg). Pada tingkat protein 15 persen memberikan pengaruh yang nyata lebih baik $(\mathrm{p}<0,05)$ terhadap produksi telur, efisiensi penggunaan pakan, berat telur dan menurunkan tingkat mortalitas dibandingkan dengan tingkat protein 17 persen. Konsumsi pakan sangat nyata menurun $(\mathrm{p}<0,01)$ dengan naiknya tingkat energi termetabolisasi dalam ransum dari 2850 sampai 3050 kkal per kg pakan. Konsumsi pakan sangat nyata meningkat $(\mathrm{P}<0,01)$ dengan naiknya tingkat protein dalam ransum dari 15 sampai 17 persen dan imbangan energi termetabolisasi: protein $(2850 \mathrm{kkal}$ per $\mathrm{kg}-15$ persen) lebih ekonomis ditinjau dari income over feed cost dibandingkan dengan imbangan lainnya. Dilaporkan terdapat efek linier positif secara signifikan pada aras protein terhadap bobot telur, daya tetas dan bobot anak ayam yang baru menetas (Menge, 1979). Lebih lanjut Rasyaf (1987) menyatakan bahwa untuk menghasilkan daya tetas yang baik perlu diperhatikan kadar protein dan energi dalam ransum disamping vitamin khususnya riboflavin, asam pantotenat, dan vitamin E serta mineral dan feed additive.

Keseimbangan kandungan protein dan energi perlu diperhatikan karena jika terlalu tinggi dalam ransum akan menurunkan daya tetas. Tillman dkk; Patel and Mc.Ginnis, 1977) melaporkan bahwa peningkatan protein dari 18 persen sampai 32 persen dalam ransum ayam pada fase perkembangan menyebabkan terjadinya penurunan daya tetas. Atas dasar uraian tersebut, maka perlu kiranya diadakan penelitian untuk mengetahui potensi tingkat penggunaan protein dan kultur khamir sebagai penyusun 
ransum terhadap mortalitas embrio "Ayam Arab".

\section{METODE PENELITIAN}

Penelitian ini merupakan penelitian eksperimental yang terbagi dalam dua tahap. Tahap pertama (10 Februari - 10 April 2000) adalah percobaan pemberian ransum dengan berbagai tingkat penggunaan protein dan kultur khamir selama 8 minggu. Periode berikutnya yaitu periode kedua adalah pengambilan telur dari ayam yang dikenai perlakuan, untuk pencatatan data utama berupa produksi telur, berat telur dan penetasan telur fertil. Periode terakhir ini membutuhkan waktu selama 5 minggu (10 April-17 Mei 2000), sehingga total waktu yang dibutuhkan untuk melaksanakan penelitian ini adalah 13 minggu.

Penelitian ini menggunakan Rancangan Acak Lengkap (Completed Randomized Design) dengan pola Faktorial (Factorial Design) 3 x 4 dengan 5 ulangan. Faktor yang digunakan dalam penelitian ini terdiri dari dua faktor yakni tingkat protein dan tingkat kultur khamir. Sebagai faktor utama adalah tingkat penggunaan protein terdiri dari A1: Ransum isokalorik (2850 kkal/kg) dengan protein 13\%, A2: Ransum isokalorik (2850 $\mathrm{kkal} / \mathrm{kg}$ ) dengan protein $15 \%$, Ransum isokalorik (2850 kkal $/ \mathrm{kg}$ ) dengan protein $17 \%$. Faktor kedua adalah tingkat penggunaan kultur khamir terdiri dari B1: Ransum isokalorik (2850 kkal/kg) tanpa kultur khamir, B2: Ransum isokalorik (2850 kkal/kg) dengan kultur khamir 0,2\%, B3: Ransum isokalorik (2850 kkal/kg) dengan kultur khamir 0,4\% dan B4: Ransum isokalorik (2850 kkal/kg) dengan kultur khamir 0,6\%.

Ayam yang digunakan dalam penelitian ini adalah "Ayam Arab" sebanyak 240 ekor umur 28 minggu yang dipelihara dalam kandang (intensif) sampai umur 36 minggu. Populasinya didapat dari Peternakan Ayam milik Syamsul Hadi di Desa Tlekung Kecamatan Junrejo Kota Administrasi Batu, Malang. kandang battery sebanyak 60 petak berukuran panjang x lebar x tinggi adalah 100 x 90 x $90 \mathrm{~cm}$. Bahan pakan yang digunakan adalah campuran jagung kuning, bekatul, konsentrat 124, produksi PT Japfa Comfeed, tepung kerang dan Top Mix. Kultur khamir yang digunakan dalam penelitian ini adalah khamir Sachharomyces cerevisiae dengan substrat bekatul yang dikembangbiakkan di Laboratorium MIPA Jurusan Kimia Universitas Brawijaya Malang.

Variabel dalam penelitian ini terdiri dari: Variabel bebas (Independent Variable) yakni Tingkat penggunaan protein dan tingkat penggunaan kultur khamir serta kombinasinya. Variabel tergantung (Dependenet Variable) melipuri mortalitas embrio. Variabel kendali meliputi breed ayam, umur produksi, pakan, tata laksana dan kondisi lingkungan/mesin tetas.

Bahan-bahan yang digunakan dalam penelitian ini terdiri dari "Ayam Arab" umur 28 minggu sebanyak 240 ekor, telur tetas hasil produksinya selama penelitian (pada umur 28 - 36 minggu produksi daya tetas telur tertinggi selama masa produksi telur, ransum isokalorik (2850 kkal/kg) dengan kadar protein yang berbeda $(13 \%, 15 \%$ dan 17\%),

BIOLOGI SEL (VOL 9 NO 2 EDISI JUL-DES 2020 ISSN 2252-858X/E-ISSN 2541-1225) PAGE 208 
kultur khamir dengan konsentrasi (0\%; 0,2\%; 0,4\%; dan 0,6\%), vaksin New Castle Disease (ND), obat cacing (piperasin, fenotiasin, dan higromisin B), vitamin anti stres, disinfektan telur (tek-trol, sarakil, lysol, dan ucarsan), formalin 40 persen dan kalium permanganat (KMnO4).

Alat yang digunakan dalam penelitian ini adalah kandang battery yang berukuran panjang x lebar x tinggi $\mathrm{cm}$ sebanyak 60 petak dilengkapi dengan perlaatan makan, minum dan penerangan, timbangan untuk menimbang sisa pakan harian, berat telur dan bobot tetas, mesin tetas berkapasitas 750 butir dan kelengkapannya, alat candling beserta kelengkapannya, tong fumigasi, kantong plastik kecil ukuran $1 \mathrm{~kg}$, gelas ukur $1000 \mathrm{ml}$, disinfectan gun sprayer, termometer dan termoregulator, hygrometer, boks ayam, ember plastik, pensil besar, isolatif kertas dan counter/ penghitung.

Ayam Arab sebanyak 240 ekor dibagi menjadi 12 kelompok, kemudian dari setiap kelompok dibagi lagi menjadi sub kelompok sebanyak 48 yang dianggap sebagai ulangan dari setiap perlakuan. Dengan demikian setiap sub kelompok terdiri dari 4 ekor ayam ( 3 betina dan 1 jantan). Selama satu minggu pertama ayam diberi ransum standar masa produksi berbentuk mash, sebagai ransum. Transisi dari ransum bentuk pellet di peternakan asal dan ransum penelitian yang berbentuk tepung. Selanjutnya dalam minggu kedua ayam diberi pakan percobaan. Tingkat protein yakni A1:13\%, A2: 15\% dan A3: 17\%) dan kultur khamir yakni B1: 0\%; B2: 0,2\%; B3: 0,4\%; dan B4: 0,6\%). Ransum percobaan dan air minum diberikan secara ad libitum sampai ayam berumur 36 minggu. Memasuki tahap kedua adalah pengambilan telur dari a yam yang dikenai perlakuan untuk selanjutnya ditimbang, agar dapat ditentikan telur yang memenuhi syarat minimum untuk ditetaskan. Dari setiap kelompok perlakuan diambil 50 butir telur fertil sehingga jumlah total yang ditetaskan adalah 6000 butir. Proses penetasan dilakukan dengan menggunakan mesin penetas. Memasuki tahap terakhir dalam penelitian ini adalah pencatatan data utama berupa produksi telur, berat telur dan penetasan telur fertil yang meliputi mortalitas embrio. Data mortalitas embrio dihitung berdasarkan jumlah embrio mati dan tidak menetas dari sejumlah telur tetas fertil yang ditetaskan dikalikan 100 persen. Selanjutnya mortalitas embrio dihitung dengan menggunakan rumus sebagai berikut:

Jumlah embrio mati dan tidak menetas

Kematian embrio $(\%)=$

Jumlah telur tetas fertil yang ditetaskan

Analisis data yang digunakan dalam penelitian ini adalah ANAVA (Analisis Varians) dengan Uji F pada taraf signifikan 5 persen. Bila terdapat perbedaan yang bermakna, dilanjutkan Uji Jarak Berganda Duncan's (Duncan's Multiple Range Test) dengan taraf signifikan 5 persen untuk mengetahui derajat beda antar kelompok perlakuan (Steel dan Torrie, 1991; Gaspersz,1994).

BIOLOGI SEL (VOL 9 NO 2 EDISI JUL-DES 2020 ISSN 2252-858X/E-ISSN 2541-1225) PAGE 209 


\section{HASIL DAN PEMBAHASAN}

\section{Mortalitas Embrio}

Rata-rata mortalitas embrio terendah sebesar 3,70 $\pm 0,70$ ditunjukkan pada kombinasi A2B3, sedangkan angka mortalitas embrio tetinggi pada kombinasi A1B1 yakni sebesar 5,64 \pm 0,38 (Tabel 1).

Tabel 1. Rata-rata dan Simpangan Baku ( \pm ) Pengaruh Tingkat Penggunaan Protein dan Kultur Khamir dalam Ransum Terhadap Mortalitas Embrio Telur Tetas Ayam (\%)

\begin{tabular}{|l|c|c|c|c|c|}
\hline \multicolumn{1}{|c|}{ Perlakuan } & \multicolumn{5}{|c|}{ Tingkat Kultur Khamir (B) } \\
\hline $\begin{array}{c}\text { Tingkat } \\
\text { Protein (A) }\end{array}$ & $0 \%(\mathrm{~B} 1)$ & $0,2 \%(\mathrm{~B} 2)$ & $0,4 \%(\mathrm{~B} 3)$ & $0,6 \%(\mathrm{~B} 4)$ & Rata-rata \\
\hline $13(\%)(\mathrm{A} 1)$ & $5.64^{\mathrm{a}} \pm 0.38$ & $5.48^{\mathrm{a}} \pm 0.00$ & $5.08^{\mathrm{a}} \pm 0.55$ & $5.28^{\mathrm{a}} \pm 0.45$ & $5.37^{\mathrm{c}} \pm 0.34$ \\
\hline $15(\%)(\mathrm{A} 2)$ & $4.67^{\mathrm{a}} \pm 0.45$ & $4.22^{\mathrm{a}} \pm 0.56$ & $3.70^{\mathrm{a}} \pm 0.70$ & $3.96^{\mathrm{a}} \pm 0.70$ & $4.14^{\mathrm{a}} \pm 0.60$ \\
\hline $17(\%)(\mathrm{A} 3)$ & $5.28^{\mathrm{a}} \pm 0.45$ & $5.08^{\mathrm{a}} \pm 0.55$ & $4.67^{\mathrm{a}} \pm 0.45$ & $4.87^{\mathrm{a}} \pm 0.55$ & $4.97^{\mathrm{b}} \pm 0.50$ \\
\hline Rata-rata & $5.20^{\mathrm{b}} \pm 0.57$ & $4.92^{\mathrm{b}} \pm 0.69$ & $4.48^{\mathrm{a}} \pm 0.80$ & $4.70^{\mathrm{a}} \pm 0.78$ & $4.82 \pm 0,71$ \\
\hline
\end{tabular}

Keterangan : Superskrip yang berbeda pada baris dan kolom yang sama menunjukkan perbedaan yang nyata $(\mathrm{p}<0,05)$

Hasil Analisis Varians (Anava) menunjukkan adanya perbedaan yang nyata $(\mathrm{P}<0,05)$ pada pengaruh tingkat penggunaan protein maupun kultur khamir dalam ransum isokalorik $(2850 \mathrm{kkal} / \mathrm{kg})$ terhadap mortalitas embrio. Setelah dilakukan uji lanjut menggunakan uji jarak berganda duncan's memperlihatkan bahwa tingkat penggunaan protein $15 \%$ atau tingkat penggunaan kultur khamir $0,4 \%$ dalam ransum memberikan nilai uji yang berbeda nyata $(\mathrm{p}<0,05)$ diantara masing- masing taraf faktor. Persentase mortalitas embrio terendah $(\mathrm{p}<0,05)$ terdapat pada tingkat penggunaan protein $15 \%$ yakni sebesar $4,14 \% \pm 0,60$, sedangkan pada tingkat penggunaan kultur khamir terdapat pada aras 0,4\% yakni 4,48 $\pm 0,80$ (Tabel 1).

Berdasarkan Tabel 1 menunjukkan bahwa tidak ada interaksi tingkat protein dan tingkat kultur khamir terhadap mortalitas embrio $(\mathrm{P}>0,05)$. Dari data tersebut memperlihatkan kedua faktor perlakuan tidak saling mempengaruhi satu dengan yang lainnya. Namun demikian, walaupun secara statistik tidak terdapat interaksi namun secara matematis menunjukkan bahwa kombinasi tingkat protein dan tingkat kultur khamir pada perlakuan A2B3 memberikan persentase kematian embrio terendah sebesar 3,70 $\pm 5,00$ keduanya menunjukkan persentase yang baik. Tingkat kematian embrio yang lebih baik dalam penelitian ini disebabkan oleh pengaruh perlakuan protein dan kultur khamir dalam ransum yang optimal, serta tatalaksana kandang yang cukup baik dan tatalaksana penetasan yang optimal.

Hasil penelitian menunjukkan bahwa pengaruh tunggal tingkat protein ataupun kultur khamir dalam ransum memberikan pengaruh yang nyata terhadap kematian embrio $(\mathrm{P}<0,05)$. Tingkat penggunaan protein $15 \%$ mapun kultur khamir $0,4 \%$ dalam ransum memberikan nilai persentase kematian embrio yang lebih baik dibandingkan dengan 


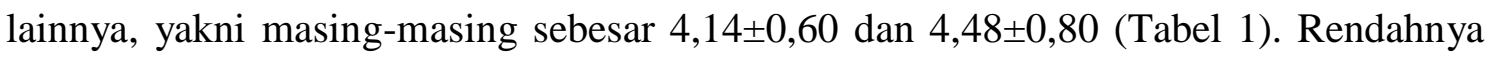
persentase kejadian kematian embrio pada pengaruh tunggal protein ataupun kultur khamir dalam ransum dalam penelitian ini merupakan pengaruh dari nutrien dalam ransum dan penetasan yang relatif lebih baik, didukung potensi genetik yang tinggi pula. Secara umum atau keseluruhan persentase yang rendah ini tidak terpisahkan dari pengaruh daya tetas. Secara matematis pengaruh berantai tersebut dapat dijelaskan dengan merinci tiga komponen nilai yakni infertilitas, fertilitas dan kematian embrio. Bila persentase daya tetas tinggi, gross dan net hatchability, maka akan memberikan persentase kematian embrio yang rendah per satuan jumlah telur tetas yang ditetaskan atau persatuan jumlah telur tetas fertil yang ditetaskan.

Embrio yang mengalami kematian di akhir penetasan (minggu ketiga) umumnya memiliki konsentrasi glukosa darah yang berkurang dan habisnya cadangan glikogen. Berdasarkan fakta tersebut maka kemampuan embrio untuk dapat bertahan hidup tergantung pada jumlah cadangan glikogen yang terkandung dalam telur serta kemampuan untuk menggunakan sumber-sumber non karbohidrat seperti sintesis glukosa dari protein tubuh/glukoneogenesis (Summer, 1995). Akibat ketidakcukupan cadangan energi tersebut ayam tidak mampu melakukan pembebasan diri dari kungkungan kerabang telur (menetas). Kecukupan energi dibutuhkan untuk proses peretakan kerabang. Oleh karena itu besar kecilnya kandungan albumen dan kuning telur sangat mempengarihi cadangan energi yang tersedia. Kekuarangan atau keterbatasan kandungan nutrien yang ada dalam telur menyebabkan hambatan terhadap perkembangan embrio. Hambatan terjadi pada mobilisasi nutrien dalam proses metabolisme embrio akibat ketersediaan nutrien yang diperlukan dalam telur kurang atau tidak seimbang. Akibat kekurangan nutrien yang lebih buruk akan menyebabkan kematian embrio selama dan sesaat setelah proses penetasan. Untuk itu, agar kecukupan nutrisi dalam telur dapat memenuhi kebutuhan metabolisme selama perkembangan embrio maka induk ayam perlu diberikan pakan yang baik sesuai dengan periode umur, berat, sistem pemeliharaan, lingkungan/iklim dan bredd (North, 1990; Tilman dkk, 1991; Wahju, 1992; Sudaryani dan Santosa, 1995).

Lemak kuning telur digunakan sebagai sumber energi dalam metabolisme embrio, yang menyediakan $90 \%$ kebutuhan energi embrional, lebih dari $80 \%$ lemak kuning telur diserap selama perkembangan embrio (Cherian dan Sim,1997; Ding dan Lilburn,1997). Sebutir telur dengan berat 60 gram menurut Tillman dkk (1991) memiliki kandungan energi sebesar $90 \mathrm{kkal}$, dihasilkan dari $0,8 \mathrm{kkal} / \mathrm{gram}$ pakan dasar yang diberikan pada induknya. Menurut Rasyaf (1992) pada periode umur 22 sampai 42 minggu atau dikenal sebagai fase pertama prestasi produksi ayam mencapai maksimal. Pada periode ini terjadi peningkatan produksi telur dari nol sampai puncak produksi kira-kira 70 sampai 85 persen, peningkatan berat badan dari 1450 menjadi 1800 gram dan peningkatan berat telur dari 35 gram menjadi 45 gram atau lebih. Selaras dengan hasil pengamatan selama 
penelitian terhadap berat telur pada umur produksi telur ayam yang digunakan dalam penelitian yakni 28 minggu produksi, tampak terdapat kesamaan distribusi berat telur dengan ketentuan menurut Marhiyanto (2000) yakni berkisar antara 35 sampai 40 gram dalam rata-rata berat telur terkonsentrasi pada berat 35 sampai 40 gram. Hasil penelitianpun menunjukkan hasil yang maksimal pada kisaran berat telur 35 sampai 37 gram.

Pertumbuhan dan perkembangan embrio yang normal tergantung pada terpenuhinya pada kebutuhan semua nutrient dalam telur, khususnya protein dan energi. Kecukupan nutrien yang terkandung dalam telur sangat dipengaruhi oleh pakan induk artinya pemenuhan kebutuhan nutrien yang dipenuhi melalui formulasi ransum yang diberikan pada ayam, yang lebih lanjut diproses dalam metabolisme tubuh induk (maternal metabolism). Kekurangan salah satu nutrien yang melebihi nilai ambang batas akan menyebabkan gangguan terhadap kenormalan metabolisme induk sehingga telur yang dihasilkan juga mengalami defisiensi nutrien tersebut. Wilson (1997) menyatakan bahwa keragaman genetik dalam absorpsi-metabolisme-deposisi berperan sebagai faktor pengaruh nutrisi terhadap viabilitas embrio. Leeson dalam Wilson (1997) menyatakan bahwa kematian yang terjadi 8 sampai 14 hari penetasan merupakan indikator sensitif adanya defisiensi pakan (diet) pada ayam, mengingat selama periode ini secara normal laju atau tingkat mortalitas embrio sangat rendah. Kekurangan nutrien atau konstituen tertentu yang ada dalam telur merupakan akibat serius dari defisiensi pakan yang diberikan pada induk.

Mortalitas embrio umumnya terjadi pada awal perkembangan embrio (minggu pertama) dan pada akhir perkembangan embrio (minggu ketiga). Defisiensi vitamin A mengakibatkan penurunan produksi telur dan daya tetas sehingga upaya suplementasi vitamin A dapat meningkatkan daya tetas. Mortalitas embrio akibat defisiensi vitamin A menyebabkan mortalitas embrio pada minggu pertama penetasan. Kelebihan vitamin A (>10.000 IU/kg) dapat menyebabkan mortalitas embrio dini (Wilson, 1997; Wahju, 1997). Umumnya kematian akibat defisiensi vitamin A disebabkan oleh malposisi dan keabnormalan perkembangan sistem sirkulasi biotin yang diperlukan untuk perkembangan normal embrio dan daya tetas. Mortalitas embrio akibat defisiensi biotin dalam telur menurut Wilson (1997) terjadi peningkatan pada minggu pertama dan minggu ketiga penetasan. Tanda-tanda embrio yang mengalami defisiensi biotin antara lain berupa peningkatan puncak mortalitas sebelum 5 atau setelah 17 hari penetasan, pemendekan tulang dan kelainan paruh.

Pattein (1978) menyatakan bahwa sekitar $8 \%$ dari embrio ayam broiler mengalami kematian pada tahapan mortalitas embrio. Mrtalitas embrio ini mengurangi nilai efisiensi reproduksi dan meningkatkan biaya produksi yang harus dikeluarkan. Tingkat mortalitas embrio yang lebih tinggi terjadi pada kalkun hingga 15\% dari total telur fertil yang ditetaskan (Bagley et al, 1990). Dalam kondisi nutrien yang rawan dalam perkembangan 
embrio, kehadiran protein albumen dapat berperan sebagai sumber asam amino yang aktif diperlukan bagi tetap berlangsungnya perkembangan embrio. Namun hal itu hanya terjadi pada hari ke-3 hingga hari ke-18 penetasan. Peningkatan kadar protein albumen terjadi secara cepat pada hari ke-15 hingga ke-18 dan setelah itu mulai menurun (Bell dan Freeman, 1997).

Mortalitas embrio selain akibat pengaruh protein ataupun kultur khamir dalam ransum juga dapat disebabkan oleh keracunan disinfektan, seperti gas fumigasi. Keracunan gas fumigasi terjadi pada awal penetasan (hari pertama) dan hari ke-17 atau ke -18 setelah telur dipindahkan ke hatcher. Mortalitas embrio selama penelitian dominan terjadi pada minggu pertama dan minggu ketiga. Hal ini selaras dengan pendapat Summers (1993) dan Jassim et al (1996) bahwa 65\% mortalitas embrio terjadi pada dua periode kritis penetasan, yakni minggu pertama, dengan puncak kematian pada hari ke-4, dan minggu terakhir (minggu ketiga), dengan puncak kematian pada hari ke-19. Menurt Jassim et al (1996) mortalitas embrio dini terjadi pada hari ke-1 sampai ke-11 sedangkan mortalitas embrio yang tergolong late embryonice mortolaty terjadi antara hari ke-12 sampai hari ke-20. Mortalitas embrio pada ayam tidak terdistribusi secara merata. Mortalitas embrio pada minggu ketiga dalam penelitian ini menunjukkan persentase tertinggi. Hal ini terkait dengan proses pembebasan diri (peretakan) yang tidak memuakan akibat akumulasi karbondioksida yang tidak seimbang dengan energi yang dimiliki embrio serta toksikasi karbondioksida menyebabkan terhambat atau terhentinya metabolisme embrio.

Menurut Bagley et al (1990) tingkat mortalitas embrio yang tinggi pada akhir penetasan diakibatkan adanya proses suksesi yang kompleks, misalnya proses maturasi, mulainya aktivitas otot, perubahan sirkulasi darah dan meningkatnya konsumsi oksigen. Perubahan sistem respirasi Chorionallantois (secara difusi) ke sistem respirasi menggunakan paru-paru juga menjadi faktor penting yang perlu dipertimbangkan dalam mengevaluasi mortalitas embrio ayam pada minggu terakhir penetasan. Sedangkan pada kasus mortalitas embrio dini, Brake et al (1997) menduga bahwa mortalitas embrio dini disebabkan oleh bertambahnya laju metabolik selama dua hari pertama penetasan sebelum terbentuknya sistem sirkulasi embrio dan kemampuan embrio melakukan pertukaran oksigen dengan baik. Hal ini dipertegas oleh Jassim et al (1996) bahwa tahapan mortalitas embrio terkait dengan perubahan metabolisme embrio yang dibedakan menjadi dua tahapan, yakni tahapan pertama (1 sampai 11 hari penetasan), merupakan periode puncak produksi asam laktat, terjadi selama perubahan karbondioksida (eliminasi karbondioksida) dan ketika mesonephros ginjal embrio mulai berfungsi untuk pertama kalinya; sedangkan tahapan kedua terkait dengan periode ketika kebutuhan oksigen meningkat secara signifikan. Mortalitas embrio dapat diestimasi dengan menggunakan model matematis multiphase analysis, Jassim et al (1996) mendapatkan puncak mortalitas embrio dini antara 1.8 sampai 2.0 penetasan dengan rata- rata total mortalitas embrio terjadi pada hari ke 1.9, sedangakn untuk mortalitas embrio pada akhir penetasan terjadi 
antara hari ke 17.8 sampai 8.9 penetasan dengan rata-rata total mortalitas embrio terjadi pada hari ke 18.4.

Menurut Bell dan Freeman (1971) embrio memiliki lethal body temperature. Pada saat menetas lethal body temperature berkisar antara 46 sampai $47,8^{\circ} \mathrm{C}$ sedangkan pada fase post embryonic life (pasca kehidupan embrional) perubahan lethal body temperature pada level atas terjadi relatif kecil. Bila suhu lingkungan dinaikkan secara perlahan-lahan kemudian secara tiba- tiba diturunkan maka lethal body temperature berkurang menjadi $45^{\circ} \mathrm{C}$. Bila dibandingkan dengan dengan temperatur penetasan yang berkisar $36-38{ }^{\circ} \mathrm{C}$ maka batas ambang lethal body tersebut cukup tinggi. Kondisi ini setidaknya memberikan batas ambang toleransi yang lebih panjang pada embrio terhadap perubahan temperatur ataupun cekaman panas.

Dalam penelitian ini penggunaan tingkat protein $15 \%$ maupun kultur khamir 0,4\% dalam ransum memberikan hasil penelitian yang paling baik. Melalui pendekatan kandungan nutrien formulasi ransum, efisiensi reproduksi telur tetas, kualitas makroskopis telur dan performance, maka protein $15 \%$ dan kultur khamir $0,4 \%$ dalam ransum secara relatif memiliki kandungan nutrien yang optimal bagi pertumbuhan dan perkembagan embrio ayam. Namun demikian, nutrien yang tersedia sangat bergantung pada pakan yang diberikan, lingkungan dan derajat kesehatan ayam induk.

\section{KESIMPULAN}

1. Tingkat penggunaan protein dalam ransum berpengaruh terhadap mortalitas embrio. Tingkat penggunaan protein yang berpengaruh paling baik adalah 15 persen.

2. Tingkat penggunaan kultur khamir dalam ransum berpengaruh terhadap mortalitas embrio. Tingkat penggunaan kultur khamir yang berpengaruh paling baik adalah 0,4 persen.

3. Tidak terdapat pengaruh interaksi antara tingkat penggunaan protein dan kultur khamir dalam ransum terhadap mortalitas embrio.

\section{SARAN}

Disarankan pada peternak ayam untuk menggunakan ransum isokalorik (2850) $\mathrm{kkal} / \mathrm{kg}$ ) dengan protein sebesar 15 persen maupun kultur khamir 0,4 persen, karena memberikan efisiensi reproduksi telur tetas yang terbaik.

\section{DAFTAR PUSTAKA}

Andayani, Susanto, Surisdiarto, Widodo dan Sjofjan. (1989). Pengaruh Penggunaan

Yeast Culture Terhadap Rasio Efisiensi Protein Ayam Pedaging. Fakultas Peternakan Universitas Brawijaya. Malang

Anggorodi. (1985). Kemajuan Mutakhir dalam Ilmu Makanan Ternak Unggas. Universitas Indonesia Press. Jakarta 
Bagley, L. G., V. L Christensen and R.P Gildersleeve. (1990). Hematological Induces of Turkeys Embryos Incubated at High Altitude as Affected By Oxygen and Shell Permebility. Poultry Science 69: 2031 -2039

Bell, D. J. and B.M. Freeman. (1997). Physiology and Biochemistry of Domestic Foul. Vol $2^{\text {nd }}$ Academic Press Inc. London. P: $614-1124$

Cherian, G and J.S Sim. (1997). Egg Yolk Polyunsturated Fatty Acid and Vitamin E Content Alters The Tocopherol Status of Hatched Chick. J. Poultry Science. 76 (12): 1753-1759

Ding, S. T and M. S Lilburn. (1997). Change in Fatty Acid Profile in Different Lipid Classes During Late Development of Turkey Embryo From Two Lines. J. Poultry Science. 76 (6):828 - 833

Djanah, D. (1985). Beternak Ayam. C.V. Yasaguna. Jakarta

Etches, R. J. (1993). Reproduction in Poultry In (G.J. King) World Animal Science: Reproduction in Domesticated Animal. Vol B-9. Elsevier Science Publishers B.V. Amsterdam. P: 493-528

Gaspersz, V. (1994). Metode Perancangan Percobaan. Penerbit Armico Bandung.

Getty. R. (1975). The Anatomy of Domestical Animal. $5^{\text {th }}$ Edition, London; W.B Saunders Company

Marhiyanto, B. (2000). Sukses Beternak Ayam Arab. Cetakan Pertama. Penerbit Difa Publisher. Surabaya

Menge. (1979). Effect of Dietary Protein and Energy on Reproduction Performance of Turkey Hens. Poultry Science. 58. P: 419 - 426

North, M. O. (1978). Commercial Chicken Production Manual. Second Edition. Avi Publishing Company, Inc. Westport. Connecticut

Patel and Mc.Ginnis. (1977). Effect of Protein and Fat in The Diets on Hatchability of Eggs and Chick Growth. Poultry Science. 56: 529 -537

Rasyaf. (1987). Pengelolaan Penetasan. Penerbit Kanisius. Yogyakarta. P:17-21

Rasyaf. (1989). Industri Ransum Ternak. Penerbit Kanisius. Yogyakarta. P:48-51

Rasyaf. (1992). Pengeolaan Usaha Peternakan Ayam Kampung. Penerbit Kanisius. Yogyakarta. P: $4-14$

Pattein, B. M. (1978). Early Embryologi of The Chick. $5^{\text {th }}$. Ed. Tata Mc Graw-Hill Publishing Company Ltd. New Delhi. P: 39 - 69

Sardjoko. (1992). Bioteknologi, Latar Belakang dan Beberapa Penerapannya. Penerbit PT. Gramedia Pustaka Utama. Jakarta. P: $12-2$

Scott, M.L., Nesheim, M. C and Young, R. J. (1982). Nutrition of The Chickens. Third Ed. and Associates, Ithaca. New York

Sefton. A.E dan Siegel, B. P. (1974). Inheritance of Body Weight in Japanes Quail. Poultry Sci. 53: $1597-1603$ 
Shin, H. T. (1988). The Effect of Yeast Culture in Swine and Poultry Ration. College of Agriculture.Sung Kyun Kwan University. Suwon. Korea

Steel and Torrie. (1991). Prinsip dan Prosedur Statistika: Suatu Pendekatan Biometrik.

Diterjemahkan B. Sumantri. Edisi ke-2. Gramedia Pustaka Utama. Jakarta

Sudaryani,T dan H. Santosa. (1995). Pembibitan Ayam Ras. Penerbit Swadaya. Jakarta. P: $1-159$

Sudjarwo. (1995). Penetasan. Fakultas Peternakan. Universitas Brawijaya. Malang Sumantra. (1993). Peranan Enzim sebagai Feed Additive Ayam Telur. Edisi April 1993. Perunggasan Indonesia. Jakarta.

Summer, J. (1995). Incubation. The Poultry Industry Council-Fact List., 95: 3 - 6 Nova Scotia

Tillman, A. D., Hartadi, H. Reksodiprodjo, S., Prawirokusumo, S dan Lebdosoekojo, S. (1991). Ilmu Makanan Ternak Dasar. Gadjah Mada University Press

Togatorop, M. H. (1981). Hubungan antara Bobot Telur Dengan Daya Tetas, Bobot Tetas pada Ayam Pedaging. Buletin Lembaga Penelitian Peternakan. No. 27

Wahju, J. (1992). Ilmu Nutrisi Unggas. Gadjah Mada University Press

Wilson, H. R. (1997). Effect of Maternal Nutritional Hatchability. J. Poultry Science. 76 (1): $134-143$ 